\title{
Academic success and resiliency factors: A case study of unaccompanied immigrant children
}

\author{
Clara Peña, Lisa Jones ${ }^{1}$, Amy Orange, Felix Simieou, and Judith Márquez \\ The University of Houston - Clear Lake, USA
}

\begin{abstract}
The purpose of this study was to identify resiliency factors that led to the academic success of three unaccompanied immigrant students in a Texas high school. We used case study methodology to examine the real life context of a phenomenon with data collected from three student participants in their natural settings using interviews, participant observations at school, and photo-elicitation. The findings indicated that internal and external protective factors attributed to the resiliency and school success of the three students who were unaccompanied immigrant children. This study is essential in understanding how resiliency factors impact the academic success of students who are dealing with the challenges of being unaccompanied immigrant children with limited immediate family support and who are English Language Learners (ELLs).
\end{abstract}

KEYWORDS: unaccompanied children, immigrant children, academic success, life story, resiliency factors

\section{Background}

In 2014, approximately 3.9 million kindergarten through $12^{\text {th }}$ grade students were enrolled in U.S. public and private schools (Passel \& Cohn, 2016). Of that number, 7.3\% were children of unauthorized immigrants (Passel \& Cohn, 2016). On average, $40 \%$ of undocumented students drop out of high school, and only $49 \%$ of undocumented students acquire a diploma and enroll in college, compared to three-quarters of peers who are documented immigrants or native born (Perez, 2014). An unprecedented increase in the number of undocumented children arriving in the U. S. from Central America without parents or guardians in the last few years has greatly challenged school districts and communities (Corona et al., 2017; Lee, 2014; Prah, 2013). Other unaccompanied immigrant children (UIC) come from Guatemala, Honduras, El Salvador, and Mexico (Jones \& Podkul, 2012; Kandel, 2017). Furthermore, Pierce (2015) noted that the largest Central American unaccompanied immigrant children population was in Texas and California.

According to Coleman and Avrushin (2017), unaccompanied immigrant children (UIC) are

\footnotetext{
${ }^{1}$ Associate Professor of Multicultural Education, University of Houston - Clear Lake, 2700 Bay Area Blvd., Houston, TX 77058, (281) 283-3551, JonesL@ uhcl.edu
} 
those children who are under the age of 18 and illegally enter into the U.S. without a primary caregiver. The landmark Supreme Court decision of Plyler v. Doe, 457 U.S. 202 (1982) mandates that states cannot constitutionally deny children in grades $\mathrm{K}-12$ a free and public education based on their immigration status (The American Immigration Council, 2016). For many decades, this ruling has protected the educational rights of immigrant students. However, newly arriving unaccompanied immigrant children face challenges in getting a formal education. These children experience similar stressors faced by other Hispanic immigrant peers, but their illegal immigrant status creates additional obstacles, such as disqualification for academic scholarships and other financial assistance, lack of emotional support from family, ineligibility for a driver's license, and constant threat of deportation (Arslan \& Yigit, 2016; Ersoy, 2015; Perez et al., 2009). While UIC have been arriving in the United States for some time, 2014 saw a great surge in arrivals (Pierce, 2015), thereby prompting an increase in attention from public policymakers of schools and communities. Thus, this qualitative case study examined the lives of three previous UIC Texas high school students from Central America. Specifically, the study explored their life experiences, personal traits, and the resiliency characteristics prevalent in their schools that contributed to and/or detracted from them attaining a successful high school education. Further, recommendations to support this student population will be offered.

\section{Review of the Literature}

Resiliency involves the inner resources or traits developed by an individual to survive life's difficult situations and the coping skills utilized to deal with trauma (Henderson \& Milstein, 2003; Ungar, 2008). Resiliency is a multidimensional construct, reliant and derived upon factors that are both internal and external to the individual (Deniz \& Ersoy, 2016; Ungar, 2008). Resiliency is a process that can be learned and promoted by families, schools, and communities (Henderson \& Milstein, 2003). Resilience happens as a byproduct of adversity and stems from: (a) a collection of characteristics that a person is born with to grow successfully despite having an underprivileged upbringing; (b) a person's ability to handle stress competently; and (c) functioning positively in response to recovering from trauma (Ungar, 2008; Yigit \& Tatch, 2017). Thomsen (2002) states resiliency is an unconscious response to a particular challenge the individual must overcome, or a response to life's changing circumstances. Children who are resilient are motivated to manage life's stresses with skills such as critical thinking and problem solving in order to accomplish goals (Arastaman \& Balci, 2013; Henderson \& Milstein, 2003; Lafer \& Aydin, 2012).

Benard (1991) states that resilient individuals are goal-oriented, have a sense of purpose, and are optimistic about their futures. Resilience manifests differently in each individual; however, it can be generically described as occurring when the accumulated protective factors such as care and support, high expectations, meaningful roles, pro-social bonding, clear boundaries, and life skills outweigh the negative accumulated effects of stressors, adversity, and risks (Benard, 1991; Brooks, 1999; Grover, 2005; Henderson \& Milstein, 2003).

While there are varying viewpoints of resiliency and its impact of student achievement (Aydin \& Kaya, 2017), Pieloch, McCullough, and Marks (2016) posit that an examination of resiliency must include viewing the topic through different dynamics such individualism, family, school, community and levels of society to gain a better idea of the experiences of "refugee children" (p. 330). Because of the increased number of the unaccompanied immigrant children (UIC) in Texas (Pierce, 2015) and their impact on public schools, it is important understand how personal resiliency factors support academic success of unaccompanied immigrant students. 
Although the literature on the academic resiliency of UIC is minimal, an awareness of certain risk factors experienced by this population is evident, as well as certain protective factors used by UIC to reach academic success (Coleman \& Avrushin, 2017; Perez et al., 2009). Much of the available research on resilience regarding undocumented immigrant students considers support from parents and families as an environmental protective factor that serves as a supportive network during difficult times (Hall \& Quinn, 2014; Perez et al., 2009; Wang, 2015). Studies have demonstrated that youth benefit by having at least one positive relationship with an adult, particularly if the adult is an educational agent, such as a teacher, counselor, or principal (De Leon, 2005; Michou et al., 2016; Perez et al., 2009; Thomsen, 2002). Aviles de Bradley (2011) found that youth possessing healthy relationships with at least one teacher or school official improved development and academic achievement. School mentors counterbalance negative incidents by inspiring optimism and self-confidence in students who are overloaded (Brown, 2004).

\section{Rationale}

Unaccompanied immigrant children as students face a myriad of problems when familial resources are unavailable (Herbst et al., 2018). This student population is at-risk and faces profound disadvantages when they begin school. Such disadvantages include loss of family, little or no support structure, traumatic experiences (Ogurlu \& Sevim, 2017; Pieloch et al., 2016), limited financial resources, legal problems (Borjian, 2018), fear of deportation, and limited English proficiency (Coleman \& Avrushin, 2017). Thus, these students require resources to support them academically. School serves as a stable mechanism in the lives of UIC, so it is incumbent upon educators and the community to offer support networks for these students. It is also imperative to understand how the life experiences and personal traits of UIC support and motivate resiliency in a Texas high school in hopes of addressing the needs of this increasing student population. To that end, the purpose of this life history research was to highlight the experiences of three unaccompanied immigrant children from Central America in a Texas high school. Specifically, we wanted to know what life experiences and personal traits of these students informed their resiliency that promoted their academic success. Moreover, an examination of school resources that supported these students while attending high school provided valuable insight into what worked for these students.

\section{Theoretical Overview}

Research on resiliency and immigrant students have looked at what makes these students academically successful in primary grades through college, internationally as well as in the United States. For example, a recent study by Gámez, Lopez, and Overton (2017) explored the factors influencing the success of undocumented students in higher education, They concluded in their findings that factors such as having mentors, resiliency, and ganas- "internal motivators" (p. 156) contributed to the successful navigation of college experiences for these students. Similiarly, the results of a qualitative study focusing on the academic success of eight undocumented students at a U.S. college conducted by Borjian (2018) revealed that pro-immigrant policies, institutional processes, and support, particularly from family, were important factors in developing academic resiliency of the participants.

The resiliency theory undergirded this research study as it provided a conceptual framework in which to gain an understanding as to why children were able to overcome adversities, 
challenges, or setbacks in their trajectory of development. Zimmerman (2013) asserts that "resiliency theory focuses attention on positive contextual, social, and individual variables that interfere with or disrupt developmental trajectories from risk to problem behaviors, mental distress, and poor health outcomes" (p. 381). In an earlier work, Fergus and Zimmerman (2005) clarified that these variables are promotive factors that operate against risk factors and are categorized as assets such as self-efficacy, self-esteem, and coping skills and as resources such as factors outside of the individual that offer support.

The conceptualized resiliency theory concepts of Zimmerman (2013) and Fergus and Zimmerman (2005) supported the focus of this study. Unaccompanied immigrant children's resiliency is illuminated by the hardships of these children and their ability to overcome obstacles. The promotive factors, assets and resources (Fergus \& Zimmerman, 2005; Toraman, Acar, \& Aydin, 2015) provide a foundation for resiliency. Assets are those individual internal factors that promote self-efficacy and self-esteem, while resources are those outside, external factors such as parental support and mentors that contribute to positive development (Zimmerman, 2013). It was with a focus on the life experiences of three unaccompanied immigrant children in a Texas high school, we hoped to gain an understanding of how these promotive factors helped these students attain academic success. Research of Pieloch et al. (2016) underscored the importance of identifying those factors that contribute to the success and resilience of migrant children as these factors potentially impact support interventions offered to these students.

\section{Researchers' Identities}

All of the researchers have worked with UIC during their careers, either as counselors or educators. During these times, we have noticed how some UIC succeeded while others struggled, both academically and socially. The first author, in particular, was interested in the factors that contributed to certain students' resiliency and how they were able to succeed when they had faced numerous difficulties in their lives. Our experiences lead to the motivation to conduct this research so we could better understand how and why some UIC succeed in the hopes that their stories can translate into strategies to help other UIC increase their resiliency and academic success.

\section{Research Purpose and Questions}

The purpose of this study was to understand the academic experiences of adolescent students who were previously UIC from Central America. The research questions considered for this study were:

1. What life experiences and personal traits of unaccompanied immigrant students support and motivate their resiliency in school?

2. What resources support resiliency in unaccompanied immigrant high school students?

\section{Methods}

We utilized exploratory case study methodology to examine the real life context of data collected from the three student participants in their natural settings (Yin, 2012). This method was appropriate because the researchers focused on exploring individual participants' experiences as unaccompanied immigrant children and the factors that contributed to their resiliency; a multiplecase study design allowed the researchers to compare and contrast across the student participants' 
experiences with each student serving as a case (Yin, 2012). A collection of data that originated from interviews, participant observation, and photo-elicitation delivered collaborative contributions of experiences from participants to the researcher (Pink, Tutt, Dainty, \& Gibb, 2010) and followed Yin's (2012) recommendation to use multiple data collection methods when conducting case study research. We focused on three UIC's experiences within high school and their perceptions of internal and external factors that contributed to their resiliency, allowing them to strive for academic success. We also included data from others in the school setting with knowledge of the three students' experiences; their perspectives allowed us to obtain a more complete picture of how the students attained academic success and to triangulate across multiple methods of data sources as well as multiple participants (Yin, 2012).

\section{Setting}

The school selected for the study was a public high school within a large school district located in Texas. In 2016, when we collected our data, there were approximately 2,682 students, with approximately 1,500 immigrant students enrolled in the school. Data from the district homeless liaison indicated 250 students met the homeless status for the current school year. The ethnic distribution of the student population in 2015-2016 was: 1.8\% African American, 94.3\% Hispanic, 3.5\% White, and 0.4\% Asian (Texas Education Agency (TEA), 2016). There were 490 English Language Learners (ELLs) at the school (TEA, 2016). The high school was located in a community that was predominantly composed of immigrants from Mexico and Central America, thus making this school appropriate for the selection of participants for this study. The district in the study had a high population of UIC that arrived from detention centers located within the state of Texas.

\section{Participant Selection}

We used purposeful sampling to select the three student participants who met the eligibility criteria (Shakir, 2002). Participants for the study were recruited from a high school in a Texas school district. The countries with the highest percentage of UIC arriving to the U.S. are from El Salvador, Guatemala, and Honduras. The three student participants selected were from El Salvador or Guatemala, were UIC upon arriving to the U.S., and established residence in the U.S. within the previous three years. The student participants were 16 years old, with similar maturity and cognitive understandings of their school participation and had the abilities to express their goals and resiliency. They were eligible to participate in the study due to their determination to obtain a high school diploma and their expressed aspirations for post-secondary studies.

The selection of adults was also purposeful, as only those in contact with the participants were asked to participate. Adults recruited for participation in the study included school personnel, such as administrators, English as a Second Language (ESL) counselor, teachers' aides, and teachers active in assisting the student participants with academic needs. The researchers requested interviews from respective teachers and school staff that were named by student participants as most supportive. When the researchers identified possible participants, adults received an invitation letter describing the study that requested their input through interviews and observations. We interviewed the ESL assistant principal, five teachers, the ESL/LEP counselor, three ESL aides, and one parent of a student participant. 


\section{Data Collection Procedures}

Before beginning the study, approval from the researchers' Institutional Review Board was obtained. The methods used to collect data included multiple interviews with each student participant, interviews with educators at the student participants' high school, an interview with one student participant's mother, classroom observations of the student participants, and photographs taken by the participants to illustrate elements of resiliency in their lives. This data provided in-depth information regarding the experiences the student participants have as students who were previously UIC.

Interviews. The interview structure utilized standardized open-ended questions; each student participant took part in six hour-long interviews over the course of the study. According to Yin (2012), the conversational nature of open-ended interviews can deliver richer information compared to surveys and questionnaires, especially in a case study with a focus on small groups. The researchers asked student participants to recount key events including their migration to the U.S., their experiences in high school, their support systems, and working towards their goals of graduation. All of the interviews took place in the student participants' school, except for the last interview, which took place at two of the student participants' homes and in a restaurant for the third student participant. The interview questions were available in Spanish and English and a certified translator translated the questions from English to Spanish to insure accuracy.

Interviews with school personnel lasted approximately thirty minutes to one hour each and focused on student/educator relationships and how they supported the UIC. We asked school personnel, such as counselors, teachers, and aides, to discuss the professional support they received from administrators to serve the three UIC. These interviews took place in classrooms or offices. One student participant's mother also agreed to be interviewed regarding her son's experiences and what she felt contributed to his academic success; this interview occurred in her home and lasted about half an hour.

Observations. Informal observations, lasting between thirty minutes and one hour, took place during the course of data collection. The purpose of the observations was to better understand the student participants' interactions with peers and school staff, their use of verbal and non-verbal communication with peers and others, and determine if patterns of activities and events they choose are congruent with information provided during the interviews. The researcher conducted four observations of the participants, both in their classrooms and in non-instructional settings.

Photo-Elicitation. The use of photo-elicitation creates a "living story" when participants share their views of the pictures taken in their environments (Creswell, 2007, p. 129). The pictures improved the articulation of the participants' stories in two ways: (a) by allowing the researchers to have access to unfamiliar spaces and (b) encouraging the youth to think thoroughly about the context of their experiences prior to the interviews (Liebenberg, Ungar, \& Theron, 2014). For this study, each of the three student participants received a disposable camera to photograph the people, places, and objects that encouraged resiliency in their lives. The pictures allowed for more direct involvement from the student participants. Each student participant was asked to take at least six

photographs; after, the researchers retrieved the cameras and had the film developed. Student reflections on the photos were discussed and thoroughly examined during the sixth interview.

\section{Data Analysis}


Data from interviews, field notes, and photographs were compared to determine patterns and identify central themes or issues. We used NVivo, a computer-assisted qualitative software analysis program, to analyze data from the interview transcripts and field notes (QSR International, 2018). Key events in the participants' histories and stories were chronologically sorted (Yin, 2012). The coding and themes determined from the data analysis were not predetermined by the researchers but emerged through the analysis process. After coding was complete, relationships were created between categories by comparing and contrasting coding from the different cases (Creswell, 2007; Yin, 2012). The themes that emerged were derived from the students' experiences and the school staff's expectations as to how each UIC participant exhibited resiliency in achieving academic success in high school.

\section{Validity}

We utilized multiple sources of data from observations and interviews of student participants, their teachers, and other pertinent school staff, and from the elicited pictures, to ensure validity, and to promote accuracy and consistency (Creswell, 2007; Patton, 2002; Yin, 2012). The triangulation of the interviews, observations, and photo data improved the study's validity and revealed complexities in the participants' histories, while minimizing researchers' biases (Creswell, 2007; Patton, 2002; Yin, 2012). The inclusion of additional data from the school data, such as policies and contemporaneous event news, allowed us to further triangulate using multiple sources of data (Yin, 2012). The researchers also utilized peer review of coding to decrease bias, with the initial coder sharing her analysis with another to ensure that prior experiences with the topic did not influence the analysis process. We also explored rival explanations (Yin, 2012) during our analysis process to further investigate any data that did not seem to fit our initial conclusions. We used this process to broaden our themes, gain a better understanding of our participants' experiences, and consider alternate ways of interpreting the data.

\section{Findings}

The data pointed to common personal protective factors among the student participants, including high locus of control, personal competence, religiosity and spirituality, and family involvement. In the following sections, we provide profiles of the three student participants and discuss their life experiences, the school setting, climate, and institutional structures that led to success for the participants.

\section{Participant Profiles}

Diego arrived in the U.S. from Guatemala in 2016. As the eldest child, he left behind a mother and four siblings to enroll in a U.S. high school and learn English formally. Diego emigrated to the U.S. to help his family financially and to escape unsafe conditions in his country. However, the journey to the U.S. was dangerous as well. Diego shared, "It's risky, it's a life or death [decision] so you have to be resolute [about taking the trip]." On his journey to the U.S., Diego was detained by the U.S. Customs and Border Protection and subsequently handed over to the Division of Administration for Children and Office of Refugee Resettlement (ORR), where he was detained for 20 days. At the time of data collection, Diego was living with two of his uncles.

Vicky emigrated from El Salvador because of the declining health of her mother. Vicky 
became one of the primary care givers of her ailing mother and younger brother. Because of this, she missed many months of school. Once Vicky's mother's health diagnosis was labeled as terminal, her mother sent her and her younger brother to live with their father in the U.S. At the age of 14, Vicky travelled with her younger brother to the U.S., unaccompanied by adults. Their journey was difficult. For example, she and her brother were often stopped by the authorities or gang members as they traveled in buses, cars, on the train, or by foot. During one occasion, when crossing between the El Salvador-Guatemala border, they were stopped by immigration. With a $\$ 200$ bribe to an immigration officer, they were able avoid other authorities and make it to Guatemala, where they stayed in a hotel for two days under the watchful eyes of the coyotes (human smugglers). Vicky and her brother were detained as they crossed into the U.S. and sent to a refugee shelter. After 20 days in the shelter, arrangements were made for her and her brother to fly to meet their father. Once she arrived in the U.S., she lived with her brother, father, stepmother, two adult stepsisters, and two of her stepsister's young children.

George emigrated to the U.S. at the age of 13 from El Salvador to reunite with his family and to continue his studies. It was difficult for him to leave his grandmother who had raised him for most of his life after his parents left El Salvador for a better life. Attending school was always a priority for George; however, in El Salvador, the long distance between the school and his home and the high crime rate were barriers for George to attend school. In his hometown, most were not educated because it was difficult to study and work at the same time. In his determination to go to school, George explained he would get up at 6 a.m. to get ready for the day and walk for approximately two hours to get to school. George considered himself fortunate because his parents paid for him to travel by bus to come to the U.S. instead of relying on the train for transportation, to avoid some of the possible dangers he could encounter, although he had no food or drink on the bus. The coyotes told George to turn himself in to Border Patrol rather than risk crossing the desert; he did so and was detained for a few days before being sent to a refugee shelter in a different state. Once at the shelter, he was able to call his father and was released into his aunt's custody after a month. George lived with his mother, father, and three siblings in the U.S.

\section{Life Experiences}

The information about students' life experiences affected their capacities to optimize personal traits in order to transfer skills learned from managing obstacles in one area of life to productively mitigating challenges in other areas. A number of personal traits emerged during the analysis, but the themes most strongly identified regarding individual resiliency were: 1) high internal locus of control; 2) personal competence; and, 3) family involvement. These themes represented an integrative portrait of each student participants' experiences and beliefs that guided their success in school.

High internal locus of control. Student participants discussed their behaviors related to meeting the demands of getting good grades, exceeding educators' expectations, and rising as classroom leaders. One important way the students did this was by asking for assistance in their classes. When George explained the reason he took a picture of an ESL aide, he said:

Because I think that she is part of our instruction, where we are is because she also helps us. Many times she stayed after school to talk about what we did, because in class there is not enough time to talk and well, we would stay for tutorials with her, when there was time to explain things I didn't understand better. Well, in class we hardly could understand 
anything and she would help us to understand more and we would get the best grades in the class.

A report from one ESL aide confirmed their efforts. Regarding the participants, one ESL aide commented, "They're very vocal in asking for help." The aides empathized with the students being in a new environment and facing some barriers to learning. They demonstrated a genuine desire to want to help the students do well in school and would stay after school, often on their own time, to help students. One aide added, "If they're asking for help, we're willing to stay. And it's usually the kids that care [about learning], so they need the familiar faces."

The participants also made choices focused on their academic success. As one example, George described how he wanted to play soccer, but knew he needed to work on his English skills to be successful in school. "You will not have the help from the teachers like in other classes where they help those who do not understand [English], and well, since we don't know [English], then I was scared [to start soccer this year," he shared. This demonstrates the sacrifices George was willing to make to succeed in school. This representative example provides a glimpse into how one participant managed his responsibilities and highlighting his maturity and internal locus of control; the other student participants shared similar experiences.

Personal competence. Despite being young adolescents, maneuvering difficult circumstances in Central America and during their journeys to the U.S. seemed to increase the student participants' self-efficacy. For example, Vicky traveled to the U.S. with her younger brother, keeping them both safe along the way while navigating multiple risky situations, including the time when they had just crossed the river at the U.S.-Mexico border and heard a truck through the trees. Her brother began yelling that Immigration was coming and they should run. Vicky said she reacted quickly by pulling him by the ear and telling him they would not run, as she had been warned by her mother that immigrants who run sometimes get shot. Thus, Vicky felt this was one way she kept her brother safe, exhibiting a maturity level far beyond her age.

By comparing the lives they had in Central America to their lives in the U.S., past experiences were beacons for promoting individual resiliency in the three student participants. Diego shared, "I'm the oldest. And I went to school [in Guatemala] but I also worked." He also described how he had to find money to buy medicine when his mother was sick. As another example of competence, Vicky explained that she had a type of dyslexia, which made learning math very difficult in her home country. After moving to the U.S. and becoming less burdened with the worry of taking care of her family, she was able to overcome her learning disability and to do well in math (Carothers \& Parfitt, 2017). These examples demonstrate how the student participants exhibited personal competence in their lives, seeming to result in their feelings of confidence.

Family involvement. Each of the student participants attributed their academic successes to their families' involvement in their educations. The student participants were able to progress in their educational pursuits by knowing their families supported them and expected them to be successful in school. The UIC in this study received support from their families, including siblings and extended family, whom also encouraged their progress. All of the students felt encouraged by their families to focus on their educations. Vicky shared:

The only thing I have to worry about is school. I no longer worry about when the light bill comes. I never know when they go buy groceries. When I look the refrigerator is full. When I look at my phone, it is already paid. It is like they don't give me anything to worry about except for school. 
The other participants shared similar experiences, offering evidence that they received support from their families in attending school as well. All of the participants felt the family support allowed them to be successful in their academic pursuits.

Diego, George, and Vicky realized their life experiences shaped them and made them stronger. During the interviews, they each expressed appreciation for the improved circumstances in their present lives. This mindset was evident when they were each asked how they thought their lives would be different if they had been born in the U.S. All three had similar answers and expressed that they would probably not appreciate their present circumstances, they would not take learning seriously, and the opportunities available to them would be taken for granted and unused. If they had been born in the U.S. they would not be aware of how difficult life is for those living in foreign countries. Vicky explained:

... because they [those born in the U.S.] don't have to experience the difficulties that others have experienced, they can't think the same way we do. I think that suffering is the key, it is the key that makes you open your mind, mature, think differently, think like, like an adult maybe, but like a young adult.

The students' comments illustrate their perceptions of how their experiences made them who they are. They acknowledged that the difficulties they had endured made them stronger and more appreciative for the educational opportunities available to them in the U.S.

\section{Religiosity and Spirituality}

The topic of religiosity and spirituality was not specifically included in the interview questions. However, as they responded to other interview questions or described people in their photos, this theme emerged as student participants frequently spoke about their beliefs in God and his assistance in guiding their lives. Although the student participants had strong religious practices in their countries of origin, in the U.S. they demonstrated their spirituality by praying often and relying on God's assistance. They reported their faith protected them, eased their fears, permitted safe journeys to the U.S., and increased their confidence in their abilities to endure. One participant stated, "I believe in God. I always talk to him, in my prayers. Right? I always ask God for everything I want or always [I pray to him] if something happens to me." In Diego's case, his uncles did not regularly attend church, but he still relied on his faith. He shared, "I confide in God. And I always tell him, in my prayers, I always ask God for the things I want and if something happens to me." All of the student participants felt that their success was at least partially attributed to their faith in God.

As demonstrated through the data in this section, these students valued their opportunities in the U.S. and drew strength from their previous experiences to be successful. They also relied on family members and religion for support. However, they also received support and encouragement at their school, as their educators strived to create a positive school climate.

\section{School Culture and Climate}

The ESL program of the school also promoted resiliency in this group of students academically, socially, and emotionally. The school employed an ESL assistant principal; she cultivated positive relationships between teachers and administrators that created a supportive climate for students. The ESL assistant principal purposefully selected teachers who could encourage UIC in their educational pursuits. She explained that she needed ESL teachers who were 
passionate about teaching ELL students. She related her selection of appropriate teachers for the ESL classes:

And I was very, very fortunate enough to have an amazing teacher and he's a third year teacher, passionate about ELLs. He's a Spanish speaker, loves Biology, good teacher and was on board and then we found an Algebra 1 teacher and that's the key.

In addition to finding capable, supportive teachers, there was a focus on providing individual attention to students to address their academic needs. After realizing that ELL students were not making progress, the ESL assistant principal decided they needed an ESL Academy on campus. She said:

I really got to delve into TELPAS (Texas English Language Proficiency Assessment System) scores and it bothered me that we don't do any differentiation for beginners. We can't meet their linguistics needs if we are not really targeting it, so that's our big move now. I was doing as much research as I can and they certainly had a lot of success with the ESL academies. We can't just go build a newcomers center right now, but [I have to focus on] what can I do now. Well now, I can make a little mini one [here on campus].

To improve student learning, ELL students are now grouped based on their TELPAS scores. The assistant principal shared that this helps teachers better target instruction to the students.

In addition to academic support, the students' histories indicated they needed a safe school with dependable, encouraging educators. According to the student participants' accounts, caring and supportive relationships were forged on campus from a network of adults and peers. The student participants and educators created a cohesive environment. Students felt supported and cared for by their teachers, who set high expectations and determined means to help students achieve academically. The history teacher explained to students that she led an "untraditional" lifestyle so she could focus on education:

As a female, as Hispanic, many times the students will say, "Well how many kids do you have?" and I say, "Do you see rings on it?" and they would say, "No". That means that I have chosen to do things another way. I've chosen to first, focus on my education and then I'll focus on that... and I don't regret it. So I say, "You are my children, you are what I wake up for in the morning, you are who I pray for and I will do whatever it takes to make you succeed whether that means being strict or whether that means being fun." Whatever it takes we will do it.

Several teachers in the study expressed similar sentiments of being willing to do whatever it takes to help their students be successful in school. The students also knew their teachers would help them as much as possible, and trusted them to provide support.

Teachers established trust by being available for the students, even after regular school hours. George shared, "She [his history teacher] always helps us. She has two jobs. She works in another place at night, but she helps us in tutorials because she wants us to be at the same level as the other [students]." George also explained how his history teacher would use the second half of the class period to work with George and other students in small groups to thoroughly explain a confusing lesson. This was a common experience for the student participants, with each providing numerous examples of how their teachers and aides provided academic and emotional support for them.

Teacher expectations. The teachers consistently set high, but attainable, expectations for the students, modeled accountable behaviors that the students also reciprocated, maintained open and honest dialogue with the students so that they would understand the path to success and achieving their goals. One student commented, "They [the teachers] would always tell us to do our 
schoolwork, to behave well, and always, if we had a problem or a need, ask Ms. Ortega [the ESL counselor]." A teacher described how she tried to motivate students with rewards, saying, "I know this may sound funny, but [I give] prizes. They love doughnuts, they're very competitive. I provide that. I also write little notes to them." She sets expectation with students by talking to them regularly about their grades. She stated:

I also never pass out their grades in public. So I pass out their grades privately and at that time I'll say, "You're doing good, but where you're doing very good let's continue" or "You need to come and see me and so I have a tutoring ticket, if you get that ticket, you have to show up." And they always have an opportunity.

She explained that students who did not show up for tutoring received detention. By communicating honestly with them and maintaining high expectations, students knew what their teachers expected and worked hard to attain their goals. The teachers tried to keep students motivated and treated the students with respect, creating a positive, safe school environment.

Support for families. Social support was also available to the UICs' parents and guardians to support students' educational progress. Parents were invited to school to meet teachers, other parents, and to see their children's academic successes. The parent engagement counselor explained a program she offered to parents:

The parents take courses and each course is designed to start to prepare them for how to deal with their high school student, or how to deal with their students in terms of education success, like how do you get your kid to college. We really are trying to provide a lot of support to keep them informed about what it takes to get the student to go to college.

Although parents were not always willing or able to participate in programs at the school, the assistant principal recognized the school has to continue efforts to reach out to them. George's mother said she enjoyed the ESL/LEP award ceremony at the end of the year after George received three certificates of achievement. She said, "I was very proud and happy when they called my son [to receive his awards]. If you would have seen, I even cried." This demonstrates that even if not all families participate in the available activities, they are important to those who take advantage of them.

\section{School Institutional Structures}

Institutional structures encompassed curriculum and instruction, professional development, and post-secondary preparedness and extracurricular activities. As older students and recent immigrants to the U.S., the UIC in this study primarily accessed these institutional structures through the ESL Program.

Curriculum and instruction. The school the participants attended included teacher training with multiple methods of instruction suitable for multiple learning styles. Staff development through yearly Sheltered Instruction Observation Protocol (SIOP) trainings for ESL teachers promoted teaching practices that incorporated an assortment of instructional strategies to engage ESL students in deeper levels of learning (Inceli, 2015). For example, collaborative learning was highly regarded by the teachers in this study. Students and teachers reported that UIC seemed to learn faster when they worked with peers in small groups. George took a picture of a group of students in one of his classes. He explained that he found small groups were helpful for his learning:

What one person doesn't know the other will know and we help each other... Well the more help we have, the better. Moreover, better learning and well, how do I say it, one may 
not know many things, but another [person] knows and that's how we help each other. Teachers and aides frequently echoed these sentiments as well, as did the other student participants. The reading teacher described how she organized her classes to help the students:

I have my classes divided into two groups and I have a kidney shaped table in my room. We do small group instructions so half of the class will be there with me and the other half will be on the computers doing ESL reading SMART, which is an online academic-based program created especially for English learners. And the small group construction, that small group setting, lowers the affective filter so that the students feel more comfortable and they're more willing to speak out and everyone participates.

By using small group instruction in classes, students felt more comfortable speaking and appreciate the chance to learn from their peers, as evidenced in the quotes above.

Professional development. Teachers and aides were provided with trainings to help them work with ELL students. By devoting the time and resources to this, the school and district personnel demonstrated their desires to help the students be successful. One example of professional development was the SIOP training, which the ESL teachers received. The framework for SIOP included a variety of strategies that are useful for all students, but specifically for ELL students. Teaching practices included scaffolding, student engagement, differentiated instruction, content objectives, and high order thinking skills. Teachers received SIOP training throughout the year. The ESL assistant principal shared that she wants all teachers to eventually receive SIOP training:

We send [the ESL teachers] to SIOP training to teach them how to use strategies to support language acquisition and content in their classrooms. We tried to get every single one of our teachers with that training. We are currently moving to promote ESL certification for most of our teachers.

Other professional development opportunities included student engagement strategies, and identifying and understanding issues faced by students of lower socioeconomic status. Pursuant to the McKinney-Vento Homeless Education Assistant Act, campus administrators and guidance counselors received professional training to identify and aid unaccompanied youth, or students who are considered homeless because they do not have a regular residence. Although some immigrant students fell into the classification of "homeless," the training did not include specific information regarding immigrant or UIC students. The district did not provide other training specific to immigrant students.

Post-secondary preparedness and extracurricular activities. Although the school had several vocational classes, clubs, and prepared students for college through advocacy, parent learning, and college and career planning, the student participants did not fully take advantage of these classes or services. Only Vicky participated in extracurricular during the study; Diego and George felt they needed to learn English well so they could be successful and chose to not participate. However, George wanted to play soccer the following year, showing that he wanted to be more involved once he felt a bit more comfortable with the academics.

Students felt that they received considerable guidance regarding post-secondary school. They reported the ESL counselor, Ms. Ortega, often talked to them about the process of going to college and the importance of having a high grade point average (GPA). Ms. Ortega shared that in order for UIC students to graduate, they required emotional, physical, and mental health to better adapt to their roles as students. She stated:

The ESL students don't know about the [school] system and how to graduate successfully and get into a college. They don't need to have the lowest GPAs if they know what they 
are doing. Their families are not usually knowledgeable about our education system. I help them learn about the system. I talk to them a lot. I tell them to talk to their teachers all the time about their grades. They need to have a relationship with the teachers. They need high grades to get good GPAs.

Both students and staff felt that numerous resources regarding post-secondary schooling were made available to UIC and their families. Their families trusted the support they received; George's mother shared that she appreciated the help he had received from the school staff and knew they would help him find the right university for him.

\section{Discussion}

A combination of internal and external protective factors influenced the UIC's perspectives to increase their resiliency. Personal traits such as a high internal locus of control, goaldirectedness, and altruism developed a resourcefulness to convert life experiences into useful skills transferrable in the school setting. Previous studies suggest that these protective factors decreased negative effects brought about by risk factors (Carlson et al., 2012; Damgaci \& Aydin, 2018; Perkins \& Jones, 2004). The personal protective factors encouraging academic success among this study's student participants resembled those found in Benard's (1991) research on resilient children, including: high internal locus of control, personal competence, religiosity and spirituality, and caring relationships with family and others.

Students' home lives were conduits to further strengthen and develop resiliency. The UIC in this study lived with family members and received considerable support from them; this may have contributed to their resiliency. Arastaman and Balci (2013) found support from family is a strong external resiliency factor for students. Any trauma or setback students encountered from their lives in their countries of origin did not appear to create psychological trauma or negate their motivation to succeed in school due in part to their families' support (Porche, Fortuna, Lin \& Alegria, 2011).

Raghallaigh (2011) found that immigrants often used religion as a way to cope with different types of stressors and challenges. The belief in a higher power, or God, gave student participants a sense of control to deal with the challenges they faced. Religiosity and spirituality were accessible constructs to the student participants because these beliefs were integrated into their daily lives by their families of origin (Raghallaigh, 2011).

Contrary to Decapua and Marshall's (2011) findings that immigrants who were proficient in capitalizing on difficult situations in their lives were not as capable in school due to a limited understanding of and unfamiliarity with the U.S. academic system, the student participants in this study successfully utilized self-efficacy to ascertain insights from past experiences to benefit them in the classroom. Bandura (2006) reported that adolescents with high self-efficacy are committed to goals providing them with a purpose and a sense of accomplishment. To meet objectives, the student participants organized their lives in ways to accomplish the end results, despite enduring troubles along the way.

Henderson and Milstein (2003) stated schools promote resiliency by fostering an environment where students develop close relationships with adults, learn how to problem-solve, and are encouraged to achieve appropriate, attainable goals. Results from this study reveal a resiliency-promoting school setting in which institutional structures, school culture and climate supported student learning. Critical to students' resiliency-building were the educatoradministrator and the educator-student relationships; positive relationships between teachers and 
administrators cultivated a supportive climate for students. Educators also fostered positive relationships with the students. Perez et al. (2009) found environmental factors promoting academic resilience amongst UIC included developing "relationships with supportive adults and peers" (p. 174). Teachers also promoted resiliency by setting high and attainable expectations for the UIC, aligning with Henderson and Milstein's (2003) research which demonstrated that setting attainable goals for students promoted resiliency by elevating their participation to meaningful learning.

While viewing the academic success of the three student participants through the resiliency theory lens, we assert that the individual student's internal factors influenced their self-efficacy and self-esteem (Fergus \& Zimmerman, 2005; Zimmerman, 2013). Moreover, the outside resources of strong faculty relationships and school support systems contributed to their success as well. Recent research studies (Borjian, 2018; Gámez et al., 2017) lend support to earlier research (Fergus \& Zimmerman, 2005; Zimmerman, 2013) asserting that family, school, and community support systems, along with the personal motivation and inward desire to succeed, were some factors that contributed the resiliency of UIC.

\section{Limitations}

Details gathered from the small sample of student participants were limited in scope and context. The unique experiences of the student participants and information from the school where the study took place cannot be generalized to the overall UIC population. A lack of representation of students with other characteristics, such as UIC from countries other than Central America, UIC that did not live with family members, and students that did not have supportive homes or school environments also posed limitations.

\section{Implications}

Young students who emigrate to the U.S. alone face challenges on their journey and in schools they may attend. It is through their internal factors and outside resources (Fergus \& Zimmerman, 2005; Zimmerman, 2013) that individual desires to overcome adversities cultivate their resiliency. This study sought to highlight some the life experiences of three unaccompanied immigrant children from Central America in a Texas high school, and examine those personal traits of these students that informed their resiliency to promote their academic success. The individual protective factors of being independent, altruistic, goal-oriented, with excellent problem-solving skills, a strong faith in God, and access to a supportive family were strengths for the participants. School structures available in the high school in this study provided a supportive and caring environment for students to excel academically. To further advance the academic achievement of UIC as students, we offer that: (a) schools should implement a formal voluntary mentoring program for UIC to assist struggling students who seek assistance with social emotional support or basic needs would prove instrumental with this student population; (b) provide professional development for teachers that include cultural sensitivity and linguistic diversity training in addition to SIOP training currently provided to ESL teachers (Center for Applied for Linguistics, 2017) (c) set academic expectations that promote resiliency building on campus through regular administration and instructional staff conversations and trainings; and (d) select teachers who are the "right match" for working with UIC, and provide those teachers extra time to plan with each other to discuss teaching strategies that encompass resiliency building. 
The purpose of this research study was to highlight the life experiences of three students who emigrated to the U.S. as unaccompanied immigrant children and were enrolled in south Texas high school. We sought to identify internal factors that contributed to the building up of resiliency for these students and impacted their academic achievement. Their stories are the stories of many students who come to the U.S. without family members, limited to no English, and hardships that impact their survival. It is through their narratives and an understanding of the factors that undergirded their resiliency that educators and policymakers can continue to access and revamp practices and policies to better serve the needs of this unique student population.

\section{References}

American Immigration Council (2016, October 24). Public education for immigrant students: Understanding Plyler v. Doe. Retrieved from https://www.americanimmigrationcouncil.org/research/plyler-v-doe-public-educationimmigrant-students

Arastaman, G., \& Balci, A. (2013). Investigation of high school students' resiliency perception in terms of some variables. Educational Sciences: Theory \& Practice, 13(2), 922-928.

Arslan, S. \& Yiğit, M. F. (2016). Investigation of the Impact of Emotional Intelligence Efficacy on Teachers' Multicultural Attitudes. Journal of Education and Practice, 7(11), 147-157.

Aviles de Bradley, A. M. (2011). Unaccompanied homeless youth: Intersections of homelessness, school experiences and educational policy. Child \& Youth Services, 32, 155-172. https://doi.org/10.1080/0145935X.2011.583176

Aydin, H. \& Kaya, Y. (2017). Educational Needs and Barriers for Syrian Refugee Students in Turkey: A Qualitative Case Study. Intercultural Education, 28(5), 456-473.

DOI:10.1080/14675986.2017.1336373

Bandura, A. (2006). Self-efficacy Beliefs of Adolescents. Greenwich, CT: Information Age.

Benard, B. (1991). Fostering resiliency in kids: Protective factors in the family, school, and community. Portland, OR: Western Center for Drug-Free Schools and Communities. Retrieved from the ERIC database. (ED335781)

Borjian, A. (2018). Academically successful Latino undocumented students in college: Resilience and civic engagement. Hispanic Journal of Behavioral Sciences, 40(1), 22-36. doi:10.1177/0739986317754299

Brooks, J. G. (1999, December 30). In search of understanding: The case for constructivist classrooms. [Review of the book, by C. Halpern]. American Journal of Qualitative Research, 1(1), 32-36.

Brown, W. K. (2004). Resiliency and the mentoring factor. Reclaiming children and youth, 13(2), 75-79.

Carlson, B. E., Carriatore, J., \& Klimek, B. (2012). A risk and resilience perspective on unaccompanied refugee minors. National Association of Social Worker, 57, 259-269. doi: $10.1093 / \mathrm{sw} / \mathrm{sws} 003$

Carothers, D. \& Parfitt, C. (2017). Disability or Language Difference: How Do We Decide? American Journal of Qualitative Research, 1(1), 1-12.

Center for Applied Linguistics. (2017). Foundational research on the SIOP Model. Retrieved from http://www.cal.org/siop/about/history.html

Coleman, D., \& Avrushin, A. (2017). Education access for unaccompanied immigrant children. 
Chicago, IL: Center for the Human Rights of Children. Retrieved from https://www.luc.edu/media/lucedu/chrc/pdfs/hbelle118_CHRC201709v5\%20(1).pdf

Corona, R., Velazquez, E., McDonald, S., Avila, M., Neff, M., Iglesias, A., \& Halfond, R. (2017). Ethnic labels, pride, and challenges: A qualitative study of Latinx youth living in a new Latinx destination community. Journal of Ethnic and Cultural Studies, 4(1), $1-13$.

Creswell, J. W. (2007). Qualitative inquiry and research design: Choosing among five traditions (2nd ed.). Thousand Oaks, CA: Sage.

Damgaci, F. \& Aydin, H. (2018). What we can learn about multicultural education from Social Media. EURASIA Journal of Mathematics, Science and Technology Education, 14(3), 797-810. DOI: 10.12973/ejmste/80945

Decapau, A., \& Marshall, H. W. (2011). Reaching ELLs at risk: Instruction for students with limited or interrupted formal education. Preventing School Failure, 55(1), 35-41. https://doi.org/10.1080/10459880903291680

De Leon, S. (2005). Assimilation and ambiguous experience of the resilient male Mexican immigrants that successfully navigate American higher education. (Unpublished doctoral dissertation). University of Texas, Austin.

Deniz, M., \& Ersoy, E. (2016). Examining the Relationship of Social Skills, Problem Solving and Bullying in Adolescents. International Online Journal of Educational Sciences, 8(1), 1 -7.

Ersoy, E. (2015). Assessment of Adolescent Perceptions on Parental Attitudes on Different Variables. Journal of Education and Training Studies, 3(5), 165-176.

Fergus, S., \& Zimmerman, M.A. (2005). Adolescent resilience: A framework for understanding healthy development in the face of risk. Annual Review Public Health, 26, 399-419.

Gámez, R., Lopez, W., \& Overton, B. (2017). Mentors, resiliency, and ganas: Factors influencing the success of DACAmented, undocumented, and immigrant students in higher education. Journal of Hispanic Higher Education, 16(2), 144-161.

doi: $10.1177 / 1538192717697755$

Grover, S. (2005). Advocacy by children as a causal factor in promoting resilience. Childhood, 12, 527-538. doi: 10.1177/0907568205058618

Hall, N. \& Quinn, R. (2014). Parental Involvement at the High School Level: Parents' Perspectives. Journal of Ethnic and Cultural Studies, 1(1), 13-21.

Henderson, N., \& Milstein, M.M. (2003). Resiliency in schools: Making it happen for students and educators. Thousand Oaks, CA: Corwin Press, Inc.

Herbst, R., Sabet, R., Swanson, A., Suarez, L., Marques, D., Ameen, E., \& Aldarondo, E. (2018). "They were going to kill me": Resilience in unaccompanied immigrant minors. The Counseling Psychologist, 46(2), 241-268. doi:10.1177/0011000018759769

Inceli, O. (2015). The Perceptions of English Teachers to the SIOP® Model and Its Impact on Limited English Proficiency. Journal of Ethnic and Cultural Studies, 2(1), 15-28.

Jones, J., \& Podkul, J. (2012). Forced from home: The lost boys and girls of Central America. New York: NY: Women's Refugee Commission. Retrieved from https://www.womensrefugeecommission.org/component

Kandel, W. A. (2017). Unaccompanied alien children: An overview. Congressional Research Service. Retrieved from http://fas.org/sgp/crs/homesec/R43599.pdf

Lafer, S. \& Aydin, H. (2012). Educating for Democratic Societies: Impediments. Journal of Social Studies Education Research, 3(2), 45-70. 
Lee, J. (2014). Schools brace for up to 50,000 migrant kids. USA Today Network, Retrieved on September 8, $2014 \quad$ at http://www.usatoday.com/story/news/nationnow/2014/08/06/public-schools-immigrant-children/13661353/

Liebenberg, L., Ungar, M., \& Theron, L. (2014). Using video observation and photo elicitation interviews to understand obscured processes in the lives of youth resilience. Childhood, 21(4), 532-547. doi: 10.1177/0907568213496652 Retrieved from http://libproxy.uhcl.edu:2507/content/21/4/532.full.pdf+html

Michou, A., Mouratidis, A., Ersoy, E., \& Uğur, H. (2016). Social achievement goals, needs satisfaction, and coping among adolescents. Personality and Individual Differences, 99, 260-265.

Ogurlu, U., \& Sevim, M. N. (2017). The opinions of gifted students about leadership training. Journal of Ethnic and Cultural Studies, 4(2), 41-52.

Passel, J.S., \& Cohn, D. (2016). Children of unauthorized immigrants represent rising share of of K-12 students. Washington, DC: Pew Hispanic Center. Retrieved from http://www.pewresearch.org/fact-tank/2016/11/17/children-of-unauthorized-immigrantsrepresents-rising-share-of-k-12-students/

Patton, M. Q. (2002). Qualitative research and evaluation methods (3rd ed.). Thousand Oaks, CA: Sage.

Perez, Z. J. (2014). Removing barriers to higher education for undocumented students. Center for American Progress. Retrieved from https://cdn.americanprogress.org/wpcontent/uploads/2014/12/UndocHigherEd-report2.pdf

Perez, W., Espinoza, R. Ramos, K., Coronado, H. M., \& Cortes, R. (2009). Academic resilience among undocumented Latino students. Hispanic Journal of Behavioral Sciences, 31(2), 149-181. doi: 10.1177/0739986309333020

Perkins, D. F., \& Jones, K. R. (2004). Risk behaviors and resiliency within physically abused adolescents. Child Abuse and Neglect, 28, 547-563. doi:10.1016/j.chiabu.2003.12.001

Pieloch, K., McCullough, M., \& Marks, A. (2016). Resilience of children with refugee statuses: A research review. Canadian Psychology, 57(4), 330-339. doi:10.1037/cap0000073

Pierce, S. (2015). Unaccompanied child migrants in U.S. communities, immigration court, and schools. Washington, DC: Migration Policy Institute.

Pink, S., Tutt, D., Dainty, A., \& Gibb, A. (2010). Ethnographic methodologies for construction research: Knowing, practice, and interventions. Building Research \& Information, 3, 647659. doi: 10.1080/09613218.2010.512193

Plyler v. Doe, 457 U.S. 202 (1982)

Porche, M. V., Fortuna, L. R., Lin, J., \& Alegria, M. (2011). Childhood trauma and psychiatric disorders as correlates of school dropout in a national sample of young adults. Child Development, 82, 982-998. doi: 10.1111/j.1467-8624.2010.01534.x

Prah, P. (2013). Number of undocumented children who cross U.S. border alone has tripled. The Pew Charitable Trusts. Retrieved from http://www.pewtrusts.org/en/research-andanalysis/blogs/stateline/2013/05/09/number-of-undocumented-children-who-cross-usborder-alone-has-tripled

QSR International. (2018). In NVivo. Retrieved from http://www.qsrinternational.com/products_nvivo.aspx

Raghallaigh, M. N. (2011). Religion in the lives of unaccompanied minors: An available and compelling coping resource. British Journal of Social Work, 41, 539-556. doi: $10.1093 / \mathrm{bjsw} / \mathrm{bcq} 136$. 
Shakir, M. (2002). The selection of case studies: Strategies and their applications to IS implementation case studies. Research Letters in the Informational Mathematical Sciences, 3, 191-198.

Texas Education Agency. (2016). Texas Academic Performance Report. Retrieved from https://rptsvr1.tea.texas.gov/perfreport/tapr/2016/

Thomsen, K. (2002). Building resilient students: Integrating resiliency into what you already know and do. Thousand Oaks, CA: Corwin Press.

Toraman, C., Acar, F., \& Aydin, H. (2015). Primary School Teachers' Attitudes and Knowledge Levels on Democracy and Multicultural Education: A Scale Development Study. Review of Research and Social Intervention, 49, 41-58.

Ungar, M. (2008). Resilience across cultures. British Journal of Social Work, 38, 218-235. doi: $10.1093 / \mathrm{bjsw} / \mathrm{bcl} 343$

Wang, T. (2015). Marginality of rural migrant students in eleven Chinese high schools. Journal of Ethnic and Cultural Studies, 2(2), 21-32.

Yin, R. K. (2012). Applications of case study research (3rd ed.). Los Angeles, CA: Sage.

Yigit, I. H., \& Tatch, A. (2017). Syrian refugees and Americans: Perceptions, attitudes and insights. American Journal of Qualitative Research, 1(1), 13-31.

Zimmerman, M.A. (2013). Resiliency theory: A strengths-based approach to research and practice for adolescent health. Health Education \& Behavior, 40(4), 381-383. doi: 10:1177/1090198113493782 
Dr. Clara Peña recently completed a doctoral degree in education and is a Licensed Professional Counselor. She currently works as a mental health therapist. E-mail: Clara_i_pena@yahoo.com

Dr. Lisa Jones is an Associate Professor of Multicultural Education at the University of Houston - Clear Lake. Dr. Jones has published articles on multicultural education and issues of diversity. E-mail: JonesL@uhcl.edu

Dr. Amy Orange is an Assistant Professor of Educational Foundations at the University of Houston - Clear Lake. Dr. Orange teaches courses in qualitative research and research methodology. E-mail: Orange@uhcl.edu.

Dr. Felix Simieou, is an Associate Professor of Educational Leadership at the University of Houston - Clear Lake. Dr. Simieou's areas of expertise include educational leadership and school community relations. E-mail: Simieou@uhcl.edu.

Dr. Judith Márquez is a Professor of Bilingual and Multicultural Education at the University of Houston - Clear Lake. Dr. Márquez conducts research in the areas of ESL and Bilingual Education. E-mail: Marquez@uhcl.edu. 